\title{
Determinants of Traders' Income at the Revitalized Vs Non-Revitalized Traditional Wet Market
}

\author{
By: \\ Anindya Rahayu Pratami ${ }^{11}$, Rakhmat Priyono ${ }^{\left.1^{*}\right)}$, Arintoko ${ }^{1)}$ \\ ${ }^{1)}$ Faculty of Economics and Business, Jenderal Soedirman University \\ ${ }^{*}$ Corresponding Author: priyonorakhmat@gmail.com
}

Submission: 13 June 2019, Accepted: 29 August 2019

\begin{abstract}
The development of modern markets has obliged wet markets to change their appearance through revitalization program in order to improve competitiveness. This study comparestraders' income in wet markets that have been revitalized (Manis Market) and that in non revitalized traditional wet market (Pon Market) in Purwokerto. This study aims to examine the effect of capital, working hour and length of business and to analyze differences in the average income of traders in both markets. The data used in this research are primary data taken from 84 respondents from Manis Market and 55 respondents from Pon Market. The results of multiple linear regression analysis show that in Manis Market, capital has a significant influence on the income of traders while other factors such as working hour and length of business do not significantly influence the income of traders. In Pon Market, capital and length of business have a significant influence on the income of traders while working hour does not significantly influence the income of traders in. Result of independent sample t-test also shows that there is significant difference in the average income of traders between Manis Market and Pon Market implying that revitalization can enhance the competitiveness of traditional market.
\end{abstract}

Keywords: Income, Revitalized Traditional Wet Market, Not Revitalized Traditional Wet Market

\begin{abstract}
ABSTRAK
Perkembangan pasar modern mengharuskan pasar tradisional untuk mengubah penampilan melalui program revitalisasi untuk meningkatkan daya saing. Penelitian ini membandingkan pendapatan pedagang di pasar tradisional yang telah direvitalisasi (Pasar Manis) dan yang belum direvitalisasi (Pasar Pon) di Purwokerto. Penelitian ini bertujuan untuk menguji pengaruh modal, jam kerja dan lama usaha dan untuk menganalisis perbedaan pendapatan rata-rata pedagang di kedua pasar. Data yang digunakan dalam penelitian ini adalah data primer yang diambil dari 84 responden dari Pasar Manis dan 55 responden dari Pasar Pon. Hasil analisis regresi linier berganda menunjukkan bahwa di Pasar Manis, modal memiliki pengaruh signifikan terhadap pendapatan pedagang, sedangkan faktor lain seperti jam kerja dan lama usaha tidak berpengaruh signifikan terhadap pendapatan pedagang. Di Pasar Pon, modal dan lama usaha memiliki pengaruh signifikan terhadap pendapatan pedagang, sementara jam kerja tidak berpengaruh signifikan terhadap pendapatan pedagang. Hasil uji-t sampel independen menunjukkan bahwa ada perbedaan yang signifikan dalam pendapatan ratarata pedagang antara Pasar Manis dan Pasar Pon yang menyiratkan bahwa revitalisasi dapat meningkatkan daya saing pasar tradisional.
\end{abstract}

Kata Kunci: Pendapatan, Pasar Tradisional Yang Direvitalisasi Dan Pasar Tradisional Yang Tidak Direvitalisasi 


\section{INTRODUCTION}

In economic activities, market plays an important role because buying and selling activities, or more often called trade, can run through the market. In economics, a place can be called a market if there is a meeting between people who want to sell and people who want to buy certain goods or services at a certain price (Giantari, Surya, Yasa, \& Yasa, 2017). Through the market, traders can distribute the products they produce for sale as a source of income. In addition to being a public service facility and also the economic center of society, the market serves as a price stabilizer, where market prices serve as a benchmark for measuring inflation and government policy makers.

There are two types of markets according to the way of transactions, traditional markets and modern markets. Traditional markets are those built and managed by the central government, regional governments, state-owned companies, private companies, consisting of shops, tents and kiosks that are owned and managed by small, medium, or cooperative traders where transactions are done through a bargaining process (Peraturan Presiden, 2007). Traditional markets provide agriculture, livestock, fisheries, and many other products needed by consumers.

The income earned by traders in the traditional wet market varies from one to the other. There are several factors that can affect the income of traders in traditional markets. One of the factors that influence traders' income is capital. Business operations cannot run without capital because every business needs capital for business operations which aims to get maximum profits (Harahap, 2017). Traders who have large capital will be very supportive of providing various goods leading to higher income. Most traders in traditional markets get capital from their savings or credit from banks.

In addition to capital, working hour may also affect the income of traders. Working hour isvery important for traders because income is obtained by traders through their time spent on trading (Nikmah, Qosjim, \& Adenan, 2015). The longer the working hours, the greater the chances of the sellers to get higher income.

Another determining factor is the length of the business. The longer the business is handled, the more experience gained, and the higher the level of ability and skills. Knowledge of consumer tastes and behavior and the extent of business network will be able to increase efficiency and revenue. So the capital factor, working hours and business duration are factors that are supposed to influence the income of traders in traditional markets.

The emergence of minimarkets and supermarkets in urban as well as rural areas has attracted the attention of customers, which could reduce the number of visitors in traditional markets which thereby affecting the income of traders. Traders in traditional markets find it difficult to compete because in addition to item variety, the prices offered in the modern market are currently quite cheap. South Purwokerto and East Purwokerto sub-districts are the areas with the highest number of supermarket and minimarkets (14 units), while the highest number of traditional wet market is observed in West Purwokerto and East Purwokerto (4 units respectively).

The number of supermarkets and minimarkets is more than the traditional wet market, $98 \mathrm{vs.}$ 27 markets. In response to this potential competition, the government has issued traditional wet market revitalization policy. According to the Agency of Industry and Trade of Banyumas Regency (2016) there are ten markets in Banyumas Regency that are revitalized. Manis Market is one of the markets that has been revitalized by the government. It is expected that with a revitalization policy, increasing the number of visitors thereby increasing the seller's income. Traditional wet markets can play a role in improving the welfare of the community which in turn can promote the national economy. The government has tried to rebuild and develop traditional wet markets with better management and improve the market appearance which is expected to increase the income of traditional wet market traders (Wibowo \& Istiqomah, 2018). However, the traders' income depands on many aspects. Those who have large capital, good management, and long working hours certainly make their income higher (Fatmawati \& Lantu, 2017; Schipmann \& Qaim, 2011).

Manis Market covers an area of 2,568 $\mathrm{m}^{2}$. After revitalization, this market provides convenience to consumers and facilitates consumers to get the items they wish because of better arrangement. Pon market has a land area of $3,724 \mathrm{~m}^{2}$ and one of the markets that has not been revitalized. However, 
revitalization certainly cannot make Pasar Manis able to get the same position as the modern market, which has large capital, good management, and long working hours certainly makes their income higher. Nevertheless, it is then interesting to find out whether the independent variables have the same effect on traders income in non revitalized traditional wet market. In this study, Pon Market was selected due to the fact that both markets are located in urban areas.

\section{METHODS}

This research used a quantitative method by analyzing primary data. Primary data were obtained from questionnaire-based interview with traders in Manis Market and Pon Market traders. The population consist of 517 traders in Manis Market and 118 traders in Pon Market. Using Slovin formula, assuming a 10 percent sampling error, 84 traders in Manis Market and 55 traders in Pon Market were randomly selected.

Data were then analyzed using two methods namely Multiple Regression Analysis and indpendent sample $t$ test analysis. Multiple regression analysis to examine the effect of capital, working hour and length of business on income received by traders in Manis Market and Pon Market. The equation of multiple linear regression can be written as follows:

$$
\ln Y_{\mathrm{i}}=\alpha+\beta_{1} \ln \mathrm{X}_{1 \mathrm{i}}+\beta_{2} \ln \mathrm{X}_{2 \mathrm{i}}+\beta_{3} \ln \mathrm{X}_{3 \mathrm{i}}+\mathrm{e}
$$

Where $Y$ is trader's income, $X_{1}$ is capital, $X_{2}$ is working hour, $X_{3}$ is the length of business, $\alpha$ is the intercept, $i$ is trader, $e$ is error term and $\beta$ is the the coefficients of elasticity.

Regarding the use of multiple regression methods, to avoid violating the assumptions of classical models, it is necessary to test classical assumptions. The classic assumption test used include the normality test, the multicollinearity test, and the heteroscedasticity test

Independent sample $t$ test is performed to compare the income of traders in both traditional wet markets, because the mean of two groups come from different groups and different objects or respondents (Sugiyono, 2014, p. 277). To determine the t-test formula, the two samples were first tested for normality and homogeneity. Normality test was performed by Kolmogorov-Smirnov test with error probability of $5 \%$. If error probability of normality test $>0.05$, data are normally distributed and otherwise. Homogeneity was tested using Levene's test. If error probability of homogeneity test $>0.05$, data are homogenous. If the data are normally distributed and homogenous, the comparison of traders' income in Manis Market and Pon Market use parametric test with independent sample ttest. If significant value of $\mathrm{t}$ - test $<0.05$, there is a significant difference between the traders' income in Manis Market and Pon Market and otherwise.

\section{RESULT AND DISCUSSION}

There is one dependent variable (traders' income) and three independent variables (capital, working hour, and length of business). Capital plays an important role in a business because as a tool of producing goods and services. Capital is a fund used to finance business establishment and daily operations activities (Harjito \& Martono, 2011, p. 256). Table 1 presents the distribution of respondents by capital per month.

Table 1. Trader's Capital Per Month in Manis Market 2018

\begin{tabular}{rccc}
\hline No & Capital Per Month (rupiah) & Frequency & Share (\%) \\
\hline 1 & $600,000-4,371,428$ & 7 & 8.33 \\
2 & $4,371,429-8,142,859$ & 24 & 28.57 \\
3 & $8,142,860-11,914,290$ & 16 & 19.05 \\
4 & $11,914,291-15,685,721$ & 17 & 20.24 \\
5 & $15,685,722-19,457,152$ & 4 & 4.76 \\
6 & $19,457,153-23,228,583$ & 12 & 14.29 \\
7 & $23,228,584-27,000,014$ & 4 & 4.76 \\
\hline & Total & 84 & 100.00
\end{tabular}

Source: Primary Data Processed, 2018 
Based on Table 1, most respondents in Manis market own capital of Rp4,371,429-8,142,859. The largest capital per month owned by respondents is $\mathrm{Rp} 27,000,000$ and the smallest capital per month is Rp600,000.

Table 2. Trader's Capital Per Month in Pon Market 2018

\begin{tabular}{cccc}
\hline No & Capital Per Month (rupiah) & The Number of Respondents (people) & Percentage (\%) \\
\hline 1 & $2,210,000-6,180,001$ & 5 & 9.09 \\
2 & $6,180,002-10,150,003$ & 6 & 10.91 \\
3 & $10,150,004-14,120,005$ & 14 & 25.45 \\
4 & $14,120,006-18,090,007$ & 12 & 21.82 \\
5 & $18,090,008-22,060,009$ & 6 & 10.91 \\
6 & $22,060,010-26,030,011$ & 5 & 9.09 \\
7 & $26,030,012-30,000,013$ & 7 & 12.73 \\
\hline & Total & 55 & 100.00 \\
\hline
\end{tabular}

Source: Primary Data Processed,2018

Based on Table 2, most respondents in Pon market own capital of Rp10,150,004-14,120,005. The largest capital per month owned by respondents is $\mathrm{Rp} 30,000,000$ and the smallest capital per month is $R p 2,210,000$.

Table 3. Distribution of Respondents by Working Hours Per Month in Manis Market 2018

\begin{tabular}{cccc}
\hline No & Working Hours Per Month (hours) & Frequency & Share (\%) \\
\hline 1 & $104-127$ & 1 & 1.19 \\
2 & $128-151$ & 10 & 11.90 \\
3 & $152-175$ & 7 & 8.33 \\
4 & $176-199$ & 21 & 25.00 \\
5 & $200-223$ & 16 & 19.05 \\
6 & $224-247$ & 20 & 23.81 \\
7 & $248-271$ & 9 & 10.71 \\
\hline & Total & 84 & 100.00 \\
\hline
\end{tabular}

Source: Primary Data Processed (2018)

The working hours of respondent is different from each other. Based on Table 3 majority of respondents in Manis Market spent 176-199 hours per month. The smallest spent 104-127 hours. Table 4 shows that most respondents spent 157-182 hours per month, while the smallest working hours are in the group of 105-130 hours per month.

Tabel 4. Distribution of Respondents by Working Hours Per Month in Pon Market 2018

\begin{tabular}{cccc}
\hline No & Working Hours Per Month (hours) & The Number of Respondents (people) & Percentage (\%) \\
\hline 1 & $105-130$ & 2 & 3.64 \\
2 & $131-156$ & 12 & 21.82 \\
3 & $157-182$ & 20 & 36.36 \\
4 & $183-208$ & 4 & 7.27 \\
5 & $209-234$ & 10 & 18.18 \\
6 & $235-260$ & 6 & 10.91 \\
7 & $261-286$ & 1 & 1.82 \\
\hline & Total & 55 & 100 \\
\hline
\end{tabular}

Source: Primary Data Processed (2018) 
Length of business represents the experience of one's business (Artaman, Yuliarmi, \& Djayastra, 2015). Table 5 shows the grouping of the length of business of the respondents.

Table 5. Distribution of Respondents by Length of Business in Manis Market 2018

\begin{tabular}{cccc}
\hline No & Length of Business (years) & Frequency & Share (\%) \\
\hline 1 & $1-6$ & 23 & 27.38 \\
2 & $7-12$ & 11 & 13.10 \\
3 & $13-18$ & 17 & 20.24 \\
4 & $19-24$ & 12 & 14.29 \\
5 & $25-30$ & 10 & 11.90 \\
6 & $31-36$ & 7 & 8.33 \\
7 & $37-42$ & 2 & 2.38 \\
8 & $43-48$ & 2 & 2.38 \\
\hline \multicolumn{4}{c}{}
\end{tabular}

Source: Primary Data Processed (2018)

Table 5 explains that the majority of respondents' length of business in Manis market is 1-6 years. Table 6 shows the majority of respondents in Pon market have been doing business between 610 years.

Tabel 6. Distribution of Respondents by Length of Business in Pon Market 2018

\begin{tabular}{ccrc}
\hline No & Length of Business (years) & Frequency & Share (\%) \\
\hline 1 & $1-5$ & 9 & 16.36 \\
2 & $6-10$ & 15 & 27.27 \\
3 & $11-15$ & 8 & 14.55 \\
4 & $16-20$ & 10 & 18.18 \\
5 & $21-25$ & 6 & 10.91 \\
6 & $26-30$ & 5 & 9.09 \\
7 & $31-35$ & 2 & 3.64 \\
\hline
\end{tabular}

Source: Primary Data Processed (2018)

Table 7. Distribution of Respondents by Monthly Income in Manis Market 2018

\begin{tabular}{cccc}
\hline No & Monthly Income (rupiah) & The Number of Respondents (people) & Percentage (\%) \\
\hline 1 & $486,800-1,239,113$ & 9 & 10.71 \\
2 & $1,239,114-1,991,427$ & 27 & 32.14 \\
3 & $1,991,428-2,743,741$ & 24 & 28.57 \\
4 & $2,743,742-3,496,055$ & 15 & 17.86 \\
5 & $3,496,056-4,248,369$ & 6 & 7.14 \\
6 & $4,248,370-5,000,683$ & 2 & 2.38 \\
7 & $5,000,684-5,752,997$ & 0 & 0 \\
8 & $5,752,998-6,505,311$ & 1 & 1.19 \\
\hline & Total & 84 & 100.00 \\
\hline
\end{tabular}

Source: Primary Data Processed (2018)

Respondents' monthly income in Manis markets shows varying income (Table 7). Of the 84 respondents, only 1 respondent received the highest income, namely in the group of 5.7 million-6.5 million rupiah, while 9 respondents had the lowest monthly income at $486-1.2$ million rupiah. It is different for respondents in the Pon market where they have lower monthly income, from 600 
Determinants of Trader's Income.... (Pratami, et al.)

thousand to 3.8 million rupiah (Table 8 ).

Table 8. Distribution of Respondents by Monthly Income in Pon Market 2018

\begin{tabular}{cccc}
\hline No & Monthly Income (rupiah) & The Number of Respondents (people) & Percentage (\%) \\
\hline 1 & $600,000-1,064,285$ & 5 & 9.09 \\
2 & $1,064,286-1,528,571$ & 21 & 38.18 \\
3 & $1,528,572-1,992,857$ & 8 & 14.55 \\
4 & $1,992,858-2,457,143$ & 7 & 12.73 \\
5 & $2,457,144-2,921,429$ & 7 & 12.73 \\
6 & $2,921,430-3,385,715$ & 5 & 9.09 \\
7 & $3,385,716-3,850,001$ & 2 & 3.64 \\
\hline & Total & 55 & 100.00 \\
\hline
\end{tabular}

Source: Primary Data Processed (2018)

It can be found the difference in average of income per month earned by traders in Manis Market and Pon Market. Traders in Manis Market have an average income per month Rp2.234.664 whereas in the Market Pon traders have an average income per month Rp1.864.949. This shows that the average income per month of traders in Manis Market is greater than the average income per month of traders in Pon Market.

Based of on a classic assumption test, result of normality test in Pasar Manis shows that P-Value is $0.589(>0.05)$. Than in Pasar Pon shows that the P Value is $0.675(>0.05)$. thus its can be concluded all of variables are normally distributed.

Table 9. Result of Multicollinearity Test

\begin{tabular}{clcccc}
\hline \multirow{2}{*}{ No } & \multirow{2}{*}{ Variable } & \multicolumn{2}{c}{ Pasar Manis } & \multicolumn{2}{c}{ Pasar Pon } \\
\cline { 3 - 6 } & & Tolerance & VIF & Tolerance & VIF \\
\hline 1 & Capital & 0.959 & 1.043 & 0.745 & 1.342 \\
2 & Working Hours & 0.986 & 1.014 & 0.745 & 1.342 \\
3 & Lengt of Business & 0.968 & 1.033 & 0.997 & 1.003 \\
\hline
\end{tabular}

Source: SPSS 16.0 for Windows

Based on Table 9, Based on Table 4.17 known that the Variance Inflation Factor (VIF) for all independent variables is below 10 and the tolerance value more than 0.1 , so it can be concluded that there is no multicollinearity problem in the independent variable used in the regression model.

Table 10. Result of Heteroscedaticity Test

\begin{tabular}{clcccc}
\hline \multirow{2}{*}{ No } & \multirow{2}{*}{ Variable } & \multicolumn{2}{c}{ Pasar Manis } & \multicolumn{2}{c}{ Pasar Pon } \\
\cline { 3 - 6 } & & t stastistik & P Value & t stastistik & P Value \\
\hline 1 & Capital & -1.073 & 0.287 & -0.525 & 0.602 \\
2 & Working Hours & -0.725 & 0.471 & 0.243 & 0.809 \\
3 & Lengt of Business & -0.123 & 0.902 & -1.968 & 0.055 \\
\hline
\end{tabular}

Source: SPSS 16.0 for Windows

From table 10 that Glejser test in Pasar Manis and Pasar Pon result showed that all independent variables used are capital, working hours, and length of business have a P-value $>5 \%$, so it can be concluded there is no heteroscedasticity in the regression model.

Table 11. Result of Multiple Linear Regression Analysis in Manis Market

\begin{tabular}{clccc}
\hline No & \multicolumn{1}{c}{ Variable } & Coeficient & p-value & t statistic \\
\hline 1 & Constant & 7.962 & 0.000 & 5.414 \\
2 & Capital $\left(\mathrm{X}_{1}\right)$ & 0.335 & 0.000 & 5.384 \\
\hline
\end{tabular}




\begin{tabular}{ccccc}
\hline No & \multicolumn{1}{c}{ Variable } & Coeficient & p-value & t statistic \\
\hline 3 & Working Hour $\left(\mathrm{X}_{2}\right)$ & 0.220 & 0.336 & 0.969 \\
4 & Length of business $\left(\mathrm{X}_{3}\right)$ & 0.008 & 0.859 & 0.178 \\
\hline
\end{tabular}

Source: SPPS 16.0 for Windows

P-value for $X_{1}$ is smaller than alpha $5 \%(<0.05)$ with $t$ statistic of 5.384 , more than $\mathrm{df}(>1.99006)$. This means that capital $\left(X_{1}\right)$ has a significant effect on the income of traders in the Manis market. $X_{2}$ and $X_{3}$ have $p$ value greater than alpha $5 \%$, and $t$ statistics of $X_{2}$ and $X_{3}$ are greater than the value of $t$ table. In other words working hour $\left(X_{2}\right)$ and length of business $\left(X_{3}\right)$ do not affect the income of traders in the Manis market.

The result of multiple linear regression analysis in Pon market is presented at Table 10.

Table 12. Result of Multiple Linear Regression Analysis in Pon Market

\begin{tabular}{clccc}
\hline No & \multicolumn{1}{c}{ Variable } & Coeficient & p-value & t Ststistic \\
\hline 1 & Constant & 7.576 & 0.000 & 5.270 \\
2 & Capital $\left(\mathrm{X}_{1}\right)$ & 0.226 & 0.019 & 2.430 \\
3 & Working Hour $\left(\mathrm{X}_{2}\right)$ & 0.498 & 0.052 & 1.990 \\
4 & Length of business $\left(\mathrm{X}_{3}\right)$ & 0.196 & 0.001 & 3.626 \\
\hline
\end{tabular}

Source: SPPS 16.0 for Windows

Regression results indicate that $p$ value for the $X_{1}$ and $X_{2}$ is greater than alpha $5 \%$, and t statistic indicates a value greater than $t$ table (>2.00758). Therefore it can be concluded that the capital $\left(X_{1}\right)$ and working hour $\left(X_{2}\right)$ significantly affect income in Pon market, while for the length of business $\left(X_{3}\right)$ has $p$ value smaller than alpha $5 \%$ and the value of the $t$ statistic is less than $t$ table, meaning that length of business $\left(X_{3}\right)$ had no effect on the income of traders.

To analyze whether there is a difference in the income of traders in Manis Market and Pon Market, normality and homogeneity tests should be performed to determine whether to use parametric test or non- parametric test. Based on Kolmogorov Smirnov test, the p-value of traders' income in Manis Market is $0.523>0.05$, and the p-value of traders' income in Pon Market is $0.583>$ 0.05 which mean that data are normally distributed. The result of Levene's test shows that the p-value is $0.379>0.05$ which means that there is a similarity between group variances thus homogenity. Because the data are normally distributed and homogenous, parametric test using independent $\mathrm{t}$ sample was performed, the result of which is presented at Table 13.

Table 13. Result for Independent Sample T-Test

\begin{tabular}{lcc}
\hline & $\begin{array}{c}\text { P-Value of Levene's Test for } \\
\text { Equality of Variances }\end{array}$ & $\begin{array}{c}\text { P-Value of t-test for Equality } \\
\text { Means }\end{array}$ \\
\hline Equal Variance Assumed & 0.379 & 0.040 \\
Equal Variance Not Assumed & & 0.035 \\
\hline
\end{tabular}

Source : Output of SPSS 16.0 for Windows

Based on Table 13, the p-value of Levene's test for equality of variances is $0.379>0.05$ which means that difference test analysis should use assumption of equal variance. The $p$-value of $t$-test for equality means with equal variance assumed is $0.040 \quad(<0.05)$ meaning that there is significant difference between traders' income in Manis Market and Pon Market. The average income in Manis Market is Rp2,234,664 and in the Pon Market is Rp1,864,949. There is a difference between the average income of traders in Manis Market and Pon Market that is Rp369,715. This shows that the average income of traders in Manis Market is greater than that in Pon Market. The greater average income of traders in Manis Market is due to the higher average working hours of traders in Manis Market, that is 203 hours per month vs. 188 hours per month. This shows that traders in Manis Market spent more time to sell their goods, thereby higher opportunity to sell more goods, leading to higher 
income. The average length of business of traders in Manis Market is also larger, that is 16 years vs. 15 years. The average traders' income in both markets according to type of their goods is presented at Table 14.

Table 14. Average Traders' Income Per Month by Type of Goods

\begin{tabular}{lcc}
\hline \multicolumn{1}{c}{ Type of Good } & $\begin{array}{c}\text { Average Traders' Income in Manis } \\
\text { Market (Rupiah) }\end{array}$ & $\begin{array}{c}\text { Average Trader's Income in Pon } \\
\text { Market (Rupiah) }\end{array}$ \\
\hline Vegetable & $2,192,660$ & $1,744,813$ \\
Groceries & $2,019,440$ & $1,884,313$ \\
Culinary & $2,634,700$ & $2,432,400$ \\
Grated Coconut & $3,065,125$ & $1,078,667$ \\
Clothes & $2,050,000$ & $1,624,333$ \\
Broilers & $2,402,500$ & $2,100,000$ \\
Tempe/Tofu & $1,748,250$ & $1,786,000$ \\
Snack & $2,115,000$ & $1,760,000$ \\
\hline
\end{tabular}

Source: Primary Data Processed (2018)

Based on Table 14, almost all types of traders in Manis Market receive a greater income than those in Pon Market. This shows that running business in Manis Market potentially earns greater income compared to doing business in Pon Market. It can be concluded that with the traditional wet market revitalization program from the government, it can affect the trader's income. Proved by higher average trader's income in Manis Market than in Pon Market. The revitalization in Manis Market makes the market more comfortable and cleaner so buyers will be more interested for shopping at Manis Market. This can increase consumer interest in visiting Manis markets.

Capital has a significant effect on the income of traders in Manis Market and Pon Market. This is in accordance with the research of Harahap (2017), Muzaffar, Huq, and Mallik (2014), Nikmah, Qosjim, and Adenan (2015), Wahyono (2017). Their research found that capital has a positive and significant effect on the income of traders. Capital is one of the important factors in increasing income. Capital is used as to finance the need to run a business. Capital is a fund used to finance business establishment and daily operations activities (Harahap, 2017). So, without the capital a company cannot operate. It can be concluded that the capital in this study is the funds or goods used by traders to finance the day-to-day trading activities. The on going business will not develop without being supported by capital. The increasing capital affect the amount of merchandise to be sold, so it will increase profit.

From the regression result, known that has no significant effect on the income of traders in Manis Market and Pon Market, because working hours in the market are limited. Usually when it is noon, the market starts to get quiet and the goods are exhausted like vegetables, then the traders close the stall and pack the goods, so the visitors in the market are reduced. Then the hypotheses which states that working hours has a positive and significant effect on trader's income in Manis Market and Pon Market is rejected. This is accordance with research of Adhikari (2012), Adhikari and Phil (2018), and Artaman, Yuliarmi and Djayastra (2015). In the results of their research found that the variable working hours has no significant affect the trader's income. Capital is a fund used to finance business establishment and daily operations activities So, without the capital a company can not operate. It can be concluded that the capital in this study is the funds or goods used by traders to finance the day-to-day trading activities. The on going business will not develop without being supported by capital. The increasing capital affect the amount of merchandise to be sold, so it will increase profit.

From the regression result, length of business known has no significant effect on income in Manis Market. In other words, the income of Manis Market traders is not effected by the length of business. The results are in accordance with research of Adhikari (2012), Adhikari and Phil (2018), and Wahyono (2017). There is a similarity on the research results, known that the length of business has 
no significant effect on the trader's income. This is due to many new traders running their business since the Manis Market is revitalized. Then traders are grouped according to the type of their goods since revitalized. For example, vegetable traders placed in one row, so emerging tight competition with fellow traders. Therefore, the hypotheses stating that the length of business has a positive and significant effect on the income of traders in Manis Market is rejected.

From the regression results known that the $P$ value of the length of business in Pon Market has a significant effect to the income variable in Pon Market and has a positive relationship, so the hypothesis stating that the length of business has a positive and significant effect to the trader's income in Pon Market is accepted. This finding is similar with the results of research byArtaman et al.,(2015) stating that the length of business has a significant effect on the trader's income. In Pon Market the length of business can effect the increase in income because, the length of business can create business experience for traders to understand howthey can attract visitors to buy their goods or in other words able to use the marketing strategy well.

Based on the result using Independent Sample T-test found that there is a significant difference between the trader's income in Manis Market and Pon Market. Manis Market is a revitalized market and the market conditions are comfortable, so it can attract the visitors (Wibowo \& Istiqomah, 2018). Traders in Manis Market have a higher average income compared to the average income of traders in Pon Market. Therefore, the hypothesis that stating There is a significant difference between average income of traders at Manis Market and Pon Market is accepted.

\section{CONCLUSIONS}

Capital has positive and significant impact on income received by traders in both markets Therefore, in order to increase income, traders should raise the capital to increase the quantity and variety and to improve the quality of goods. This can attract customers. Length of business has different effect in both markets. While it positively affects income in Pon Market, in Manis Market it has no effect. It could be due to the fact that some traders are fast learners and some have shown relatively slow response to new strategis to attract consumers. There is different findings of length of business in Manis Market and Pon Market. In Pon Market, length of business has significant effect but in Manis Market it has no significant effect because in Manis Market there are some traders who just started their business when the market has been revitalized. So, revitalization ha attratcted new traders who perform well.

This study found that there is a significant difference between average income of traders in Manis Market and Pon Market. The average income of traders in Manis Market is greater than that in Pon Market, which means that with the government program such us traditional markets revitalization by improving the quality and condition of market buildings, the income of traders in Manis Market increased. Therefore, to maintain the existence of traditional wet market, it is expected that the program can be applied to other traditional wet markets in Banyumas Regency.

The Limitations in this study are on the variables used. In this study use three variables: capital, working hour and length of business. There are other variables that are supposed to have an impact on traders' income such as age, education, location of the business, etc. So future research may consider to include these variables.

\section{REFERENCES}

Adhikari, D. B. (2012). Income generation in informal sector: A case study of the street vendors of Kathmandu Metropolitan City. Economic Journal of Development Issues, 13(1), 1-14. https://doi.org/10.3126/ejdi.v13i0.7193

Adhikari, D. B., \& Phil, M. (2018). Informal Street Food Trade: A Source of Income Generation in Urban Nepal. Economic Journal of Development Issues, 23(1), 1-17. https://doi.org/10.3126/ejdi.v23i1-2.19062

Artaman, D. M. A., Yuliarmi, N. N., \& Djayastra, I. K. (2015). Analisis Faktor-Faktor Yang MEmpengaruhi Pendapatan Pedagang Pasar Seni Sukawati Gianyar. E-Jurnal Ekonomi Dan 
Bisnis UNiversitas Udayana, 02(4), 87-105.

Fatmawati, F., \& Lantu, D. C. (2017). Evaluation of Revitalization Program Case: Cihapit Traditional Market. Journal of Business and Management, 6(1), 101-113.

Giantari, I. G. A. K., Surya, I. B. K., Yasa, N. N. K., \& Yasa, I. B. A. (2017). Development and Revitalization Strategies for Traditional Markets in Bali. International Journal of Social Economics, 45(7), 1058-1070. https://doi.org/https://doi.org/10.1108/ IJSE-09-2017-0414

Harahap, E. F. (2017). Analysis of Determinants of Income and Efforts to Improve the Welfare of Street Vendors in Padang City. European Journal of Business and Management, 9(3), 118-124. https://doi.org/https://doi.org/10.7176/EJBM

Harjito, A., \& Martono. (2011). Manajemen Keuangan Edisi Kedua. Yogyakarta: Ekonisia.

Muzaffar, A. T., Huq, I., \& Mallik, B. A. (2014). Entrepreneurs of the Streets: an Analytical Work on the Street Food Vendors of Dhaka City. International Journal of Business and Management, 4(2), 80-88. https://doi.org/10.5539/ijbm.v4n2p80

Nikmah, R., Qosjim, A., \& Adenan, M. (2015). Dampak Revitalisasi Pasar Tradisional Asembagus Terhadap Pendapatan Pedagang dan Kepuasan Konsumen di Pasar Asembagus Kabupaten Situbondo. Artikel Ilmiah Mahasiswa, 1-7.

Peraturan Presiden. Penataan dan Pembinaan Pasar Tradisional Pusat Perbelanjaan dan Toko Modern. , Pub. L. No. 122 Tahun 2007, 1 (2007).

Schipmann, C., \& Qaim, M. (2011). Submitted Article Modern food retailers and traditional markets in developing countries : Comparing quality, prices, and competition strategies in Thailand. Applied Economic Perspective and Policy, 00(00), 1-18. https://doi.org/10.1093/aepp/ppr018 Sugiyono. (2014). Metode Penelitian Kuantitatif Kualitatif dan R\&D. Alfabeta.

Wahyono, B. (2017). Analisis Faktor-Faktor Yang Mempengaruhi Pendapatan Pedagang di Pasar Bantul Kabupaten Bantul. Jurnal Pendidikan Dan Ekonomi, 6(4), 388-399.

Wibowo, A. A., \& Istiqomah. (2018). The Consumers' Perception and Frequency of Visit Before and After Wet Market Revitalization. Jurnal Bina Praja, 10(2), 183-193.

https://doi.org/10.21787/jbp.10.2018.183-193 